\title{
Balkanologie
}

Balkanologie Revue d'études pluridisciplinaires

Vol. III, n 1 | 1999

Volume III Numéro 1

\section{Politics and Inter-Confessional Strife in post-1989 Romania: From Competition for Resources to the Redefinition of National Ideology}

\section{Constantin lordachi}

\section{(2) OpenEdition \\ Journals \\ Electronic version \\ URL: http://journals.openedition.org/balkanologie/291 \\ DOI: 10.4000/balkanologie.291 \\ ISSN: 1965-0582 \\ Publisher \\ Association française d'études sur les Balkans (Afebalk)}

\section{Printed version}

Date of publication: 1 July 1999

Number of pages: 147-169

ISSN: 1279-7952

\section{Electronic reference}

Constantin Iordachi, «Politics and Inter-Confessional Strife in post-1989 Romania: From Competition for Resources to the Redefinition of National Ideology », Balkanologie [Online], Vol. III, n 1 | 1999,

Online since 03 June 2008, connection on 17 December 2020. URL : http://journals.openedition.org/ balkanologie/291 ; DOI : https://doi.org/10.4000/balkanologie.291

This text was automatically generated on 17 December 2020.

(c) Tous droits réservés 


\title{
Politics and Inter-Confessional Strife in post-1989 Romania: From Competition for Resources to the Redefinition of National Ideology
}

\author{
Constantin Iordachi
}

\section{EDITOR'S NOTE}

An earlier version of this article was presented at The Socrates Kokkalis Student Workshop: New Approaches to Southern Europe, at Harvard University, Minda de Gunzburg Center for European Studies, February 12-13, 1999.

I wish to thank Molly Abraham for revising a preliminary draft.

[Romanians], wherever they are, if they hate each-other within their own vicinity, the greatest reason for their disarray stems from the fact that some are belonging to the United Greek-Catholic cult, while others to the Eastern Orthodox cult. The former name the latter not United, while the latter name the former United. At the same time, both parts reserve for themselves that honest, brotherly and saint Christian name; if the people from these lands do not get rid of this pointless prejudice and do not overcome this old and vicious religious discord, then they will work against their own interests. Dimitrie Tichindeal, 1814. 
I myself lost any hope that the Romanian can have any positive future. So much our people is

harmed here by priests that they either

sympathize with foreigners or associate exclusively with fellows of their same religion, rather than as United with Orthodox and vice-

versa. They even do not name each other Romanians anymore, but the Orthodox call the other Popeists, while the United call those not

United - Muscals.

Liviu Andrei Pop, 1855

1 Historically, Romanian nationalism has exhibited close similarities with the ethnolinguistic type of nationalism which characterized most of the national movements in East-Central Europe : national community was defined primarily in terms of shared language and descent. However, the Romanian national ideology has encompassed also an important religious dimension, with two main components: Eastern Orthodox Christianity in the Old Kingdom and Greek-Catholicism in Transylvania. Although not valued as the most salient features of the "Romanianness", these religious elements ensured nevertheless a significant socio-political influence for the ecclesiastical leadership, which could occasionally mobilize ethno-religious loyalties for obtaining strategic political gains.

2 The aim of this paper is to explore the tempestuous post-1989 inter-confessional conflict between the Romanian Orthodox Church and the Romanian Greek-Catholic Church, and the resulting redefinition of the relationship between state and church. I am particularly interested in the way the two churches have utilized the symbolic bond between religion and national identity for legitimizing their competing interests ; and how they attempted to subsequently convert their symbolic capital into an important source of material resources. In addition, I will evaluate the overall impact of this religious conflict on the domestic and foreign policy of Romania. How can we account for the recent crisis in the relationship between the Romanian Orthodox Church and the Romanian state? Furthermore, do we assist to a nationalist political offensive, based on an emerging alliance between the Orthodox Church and nationalist parties?

3 This research is based on media ecclesiastical polemics, parliamentary debates, and various church and state documents. I employ a neo-Weberian methodological approach, which treats the church as an institution with a dual character, hierocratic and administrative-territorial. Max Weber pointed out that, as a "compulsory hierocratic association", the church has a monopoly over the manner in which salvation is to be achieved, while as a "territorial and parochial organization", the church exercises authority over an administrative-territorial area, which serves as a tax-revenue basis ${ }^{1}$. This analytical framework is useful for understanding the institutional evolution of the Church in the modern period, when the generalized process of bureaucratization and rationalization has strengthened its administrative character. Faced with an increased secular political pressure, the church has transformed into a "corporate interest group", and arrived at a compromise with the political power : in exchange for political protection and material resources, the church has assisted the state in the "domestication" of its subjects, by nationalizing the religious community and supporting the national ideology. 
4 In the same vein, I treat the Orthodox and the Greek-Catholic Churches as "interest groups". I argue that, due to the sudden liberalization of religious life, and with the inability of the political power to provide a suitable legislative framework, the GreekCatholic and Orthodox Churches have faced with an intense rivalry for material resources and spiritual pre-eminence. This rivalry led to a sharp antagonism. The Romanian Orthodox Church (ROC) refused to consider any significant patrimony retrocession toward the Romanian Greek-Catholic Church United with Rome (RGCC), openly disregarded juridical verdicts, and launched a political offensive aimed at questioning the established relationship between church and state. These actions unavoidably led to open debates between Greek-Catholic and Orthodox clerics and a succession of crises in their inter-confessional relationship. Moreover, during the conflict, both churches attempted to consolidate their political profile and to expand their privileges, by developing a symbolic-ideological hegemony in society which ultimately aimed at redefining Romanian national identity and shaping the country's path of development ${ }^{2}$. Theology left thus the ivory tower of purely ecclesiastical controversies, becoming instead a major arena of ideological confrontations in Romanian society.

\section{Pluri-Confessionalism and the Romanian National Identity : Historical Antecedents}

5 The Principalities of Wallachia and Moldova have been traditionally a part of the Eastern Orthodox Christianity, being attached to the Ecumenical Patriarchy in Constantinople. After the fall of the Byzantine Empire, Romanian Principalities contributed to the survival of the Byzantine politico-religious traditions, a role synthesized by the Romanian historian Nicolae Iorga in the formula "Byzantium after Byzantium". A central component of this legacy was the close bond between church and state, which assured high clerics considerable power and influence ${ }^{3}$. The advent of the Romanian modern national-state restricted drastically the role and influence of the Church : the reforms of Alexandru Ioan Cuza (1859-1866) secularized the patrimony of the Church and subjected it to laic control and interests. The dominant Orthodox Church succeeded however in preserving a prominent political profile. The existence of an overwhelming Eastern Orthodox Christian majority, coupled with the tradition of the old treaties ("capitulations")between the Principalities and the Ottoman Empire, which had forbidden the practice of Muslim religion on Romanian territory, favored a symbolic association between Romanian national identity and Orthodox Christianity. This association was expressed in the doctrine of the "Christian state", and was consecrated legally by article 7 of the 1866 Romanian Constitution, which read that « in Romania, only foreigners of Christian rite can acquire naturalization $»^{4}$. Later, the Orthodox Church became an important component of the process of nation- and statebuilding : the achievement of Romania's independence (1878) was soon followed by the autocephaly of the Romanian Orthodox Church from the Ecumenical Patriarch (1881) and by the establishment of the Romanian Patriarchy (1925), regarded both as a symbol of the Romanian national identity.

6 By contrast, the Romanian national community in Transylvania experienced a different socio-political history, which accounts for its pluri-confessionalism. The Transylvanian medieval political system was based on the 1437 alliance among three dominant 
"nations" - the Hungarians, Germans, and Szeklers - accompanied in 1568 by the alliance among four received religions - Catholic, Calvin, Lutheran and Unitarian. This system excluded Orthodox Romanians from significant political and civic rights. In 1700, following the conquest of Transylvania by the Habsburg Empire, a part of the local Orthodox Church united with Rome. In exchange for recognizing the authority of the Pope and certain elements of the Catholic dogma, the newly established Romanian Greek-Catholic Church (alternatively named the Romanian Uniate Church) could retain its Eastern ritual and gained access to political rights. A specific creation of the Habsburg confessional policy, the new church was shaped by the reforming policy of Joseph II : the quasi-importation of the millet system within the Habsburg Empire (characteristic until then only to the Ottoman Empire) conferred autonomy to communities delineated according to their religion ${ }^{5}$. This favored the emergence of an ethno-confessional nationalism among Transylvanian Romanians: during the $18^{\text {th }}$ century, the Greek-Catholic Church became the main catalyst of the Romanian national revival in Transylvania. Its Western educated intelligentsia played a central role in the emergence of Romanian national ideology, while its ecclesiastical center in Blaj became a symbol of Romanian national identity. In the first half of the $19^{\text {th }}$ century, the strong revival of the Orthodox Church in Transylvania animated by Metropolitan Andrei Saguna raised imperiously the problem of inter-confessional relationship within the Romanian national community, mostly because the theological and political options of the two confessions were strongly polarized: Greek-Catholics stressed the essential link between Romanian national identity and Latinity, and argued for strong political and confessional ties with Western Christianity ; by contrast, Orthodox representatives emphasized the traditional bond between Romanian national identity and Orthodoxy, and valued the historical ties with the Orthodox Ecumenical Patriarchy in Constantinople. In the eve of the 1848 revolution, when the political and inter-ethnic tensions in Transylvania were acutely raising, the strife between the Orthodox and Greek-Catholic leaderships risked to endanger the cause of the Romanian national movement in Transylvania. Therefore, lay nationalist intellectuals harbored plans for a religious unity of the Romanians : while Greek-Catholic and Orthodox theologians saw the only possibility for religious unity in the absorption of the rival religious community, lay nationalists advanced the formula of a unitary and autocephalous Romanian church, which was to encompass both religious confessions, either in complete administrative union or as separate entities. Promoted for the first time during the 1848 revolution by a resolution of the Romanian National Assembly in Blaj (May 15, 1848), the ambiguous formula of a Romanian National Church succeeded only temporarily in subordinating church interests to the newly discovered religion, nationalism: the next post-revolutionary (1848-1858) decade would be one of an unprecedented religious discord among Romanians.

7 Following the establishment of Greater Romania in 1918, the Greek-Catholic Church had to adjust its institutionalized structure to the framework of a national-state. Facing the arduous task of administrative integration and cultural homogenization among the newly acquired historical provinces of Greater Romania, the Romanian political elites tried yet again to associate both churches into a Romanian National Church and to subordinate them to the imperious task of national consolidation: the 1923 Constitution of Romania defined the Greek-Catholic and the Orthodox Churches as national churches and granted them parliamentary participation (the two were subsequently referred to as "sister-churches"). However, the Greek-Catholics' inter- 
confessional relationship with the dominant Orthodox Church continued to be strained, been characterized by an acute competition for material resources and spiritual prominence, rather than by cooperation. The Orthodox leadership never fully accepted the secession of the Greek-Catholic Church from its ranks. That is why, in 1948, when the consolidated communist regime launched a vigorous political offensive against the Romanian Greek-Catholic Church - seen as a center of Western influence and anti-Communist political resistance - a militant Orthodox leadership took advantage of those political circumstances and sponsored a putative ecclesiastical synod in October 1948, which proclaimed the religious "reunification" of Romanians within the Orthodox Church. Soon afterward, the Romanian government disbanded the Greek-Catholic Church and handed its property to the Orthodox Church. All GreekCatholics who refused to comply to the union were arrested and sentenced to prison'.

The traditional antagonism between the Orthodox and the Greek-Catholic Churches deepened during the Communist regime. The reigning Romanian Communist Party extracted its main political legitimacy from a specific combination of decayed Marxism and nationalism. National-communism developed thus as a hegemonic political ideology : those who defected from the official ideology of the Communist Party were ostracized as anti-national political figures. In this context, the Romanian Orthodox Church negotiated very early a political compromise with the Communist regime. In exchange for supporting the political propaganda of the regime, the Orthodox Church preserved a privileged political position. Surely, the Orthodox Church suffered unavoidably from the harsh secularization of the social life during communism: the atheist political power intervened brutally in ecclesiastical matters, persecuted dissident priests, restricted religious education and discouraged church attendance, while part of the religious patrimony was damaged. But Orthodox leaders remained prominent political figures, while the church enjoyed state protection and subsidies. By contrast, the Greek-Catholic Church was forbidden by the Communist regime, and could function only underground. In opposing the Communist regime, the GreekCatholics rejected also its autarchic and nationalist political culture, pleading instead for renewed political ties with the West.

\section{Politics and Inter-Confessional Strife in post-1989 Romania}

Following the 1989 political change in Romania, religious life was liberalized throughout the country: article 29 of the 1991 Constitution of Romania expressly guarantees the freedom of religious belief and the complete autonomy of legally established religious cults ; on this basis the Romanian government has recognized and provided material assistance to 15 religions cults ${ }^{7}$. However, the lack of an adequate legal framework forced various religious cults to face acute competition for material resources and political influence, which often placed them on a collision course.

First and foremost, the overall political upheaval and religious reorganization has challenged the established privileged status of the Romanian Orthodox Church. In reaction, the Orthodox leadership tried to prevent an imminent crisis of their church by consolidating and expanding its political influence. To this end, the ROC attempted to exploit its old political ties, and take advantage of its status of a dominant church, in a country in which $87 \%$ of the inhabitants have declared themselves Orthodox 
believers. The Orthodox leadership has initiated thus a comprehensive program of spiritual pre-eminence in society: numerous churches and monasteries have been (re)built throughout the country; the theological educational system has been consolidated, and religion has been reintroduced as a subject in primary schools, etc.

In spite of these gains, the Orthodox Church has experienced nevertheless a period of great insecurity for a variety of reasons. Unlike in the interwar period - and in spite of a strong Orthodox lobby - the new Romanian Constitution did not stipulate parliamentary representation for the ecclesiastical leadership ; and failed to nominate the Orthodox Church as the dominant church of the country, proclaiming instead the equality of religious cults. Orthodox leaders considered these omissions as a gross disregard of their specific interests ; in reaction, in 1994 the Holy Synod modified the Status of the ROC to unilaterally proclaim the Orthodox Church as "national, authochephalos and unitary in its organization » (art. 2). This assertion of an Orthodox symbolic national pre-eminence in the relation to other religious cults was meant to compensate an alleged material disadvantage of the Orthodox Church. Thus, Orthodox representatives bitterly denounced the offensive of Protestant and Neo-Protestant churches in Romania, claiming that they use their superior material resources in a proselytizing campaign directed specifically at Orthodox believers ${ }^{8}$. The greatest challenge to the Orthodox spiritual supremacy was posed however by the resurrection of the Romanian Greek-Catholic Church. In January 1990, a decree of the new Romanian government recognized the legal existence of the Greek-Catholic Church, while a Papal Decree reconstituted the church under the new title of the Oriental Catholic Church of Byzantine Rite and appointed archbishops for the former Greek-Catholic dioceses. Statistically, the revival of the Uniate Church was only partially successful : if in the interwar period, Greek-Catholics encompassed approximately 1500000 believers, or 7,9 \% of Romania's population, the January 1992 census registered only 228377 GreekCatholics, representing $1 \%$ of the country's population and concentrated preponderantly in major cities of Transylvania. Without a strong rural basis, the GreekCatholic revival attained thus an urban and elitist character, being animated mostly by traditional Greek-Catholic interest groups. Although it has shrunk numerically, the Greek-Catholic Church has been however greatly favored by the 1989 political change, since it could present itself as an anti-Communist collective dissident, with an essentially European vocation. The spiritual leader of the Uniate Church, Alexandru Todea, became the symbol of the martyrism and subsequent revival of GreekCatholicism in Romania after spending 16 years in prison and 25 in forced domicile arrest, he became the first Romanian Catholic Cardinal. By contrast, the Orthodox Church bore the stigma of a collaborating church : Romanian media examined largely the limited role performed by the Orthodox Church in resistance to the dictatorial regime $^{9}$. Patriarch Teoctist, the leader of the ROC and a former deputy in the Communist Great National Assembly, became a symbol of the regrettable compromises the Orthodox Church made during the communist period. As a result, his leadership was deeply contested by a significant number of believers, and even high prelates. Facing increased pressure, at the beginning of 1990 the Patriarch withdrew temporarily from the head of the Orthodox Church. His gesture was celebrated by numerous intellectuals as the beginning of a necessary process of moral reformation of the Orthodox Church. Yet the opposite occurred : profiting by the general neo-communist political resurgence after the national political elections in May 1990, Patriarch Teoctist returned in force as the head of the ROC. While he repeatedly refused to 
resign, protests against his authority from the grass-roots level within the church were crushed with the assistance of the authorities. In coping with these contestations, the Orthodox Church demonstrated thus an inability to change and re-adapt to new social demands. Instead of leading the movement for moral regeneration and introspection of the past, Orthodox leaders have demonstrated frustration and inflexibility. This conservatism of the Orthodox leadership alienated many Romanian intellectuals. The harsh Communist regime in Romania prevented the development of independent networks or civic associations. In this context, while attempting to foster the development of civil institutions "from the scratch", radical Westernizing intellectuals internalized non-academic stereotypes of an imputed hegemonic Western identity, essentializing very often the incompatibility between the mysticism and lack of social activism of the Orthodoxy and rationalist and democratic spirit of Western Christianity ${ }^{10}$. Thus, while blaming unilaterally the historical tradition of the Orthodox Church for the insufficient modernization and weakened civil society in Romania, Romanian intellectuals attempted to build civic society without, or - according to some radical variants - even against the traditional Orthodox religious component. Instead, their sympathy turned toward Greek-Catholicism, which - through its links with the Vatican - was regarded as a symbol of Romania's European vocation.

The tension between these different political expectations of the Orthodox and the Greek-Catholic Churches has been dramatically reinforced by the acute problem of the restitution of Greek-Catholic Church patrimony, which was confiscated by the communist regime upon the liquidation of the Uniate Church in 1948 and handed over to the Orthodox Church. Since its reestablishment in 1990, the Catholic Oriental Church has begun an intense and sustained campaign for restitution in integrum of its lost properties. The litigation was quickly addressed by the new political regime : in 1990, the Decree $n^{\circ} 126$ recognized the importance and the urgency of the grievance, but recommended only an arrangement through amiable negotiations between the two churches. In this way, a favorable resolution of the justified Greek-Catholics demands became dependent upon the good intentions and willingness to collaborate of the Orthodox Church, and upon the choice of believers at the local level. In fact, as it was soon proved, the ROC was very slow in considering the restitution demands of GreekCatholics. This led unavoidably to open debates among prelates and many successive crises in their inter-confessional relations. In 1992, the Greek-Catholic Church possessed two cathedrals and 212 churches; of these, only 25 were returned by the Orthodox Church, while the rest were newly built churches or were chapels "improvised" in various public buildings. The extremely tense inter-confessional relationship was expressed by the fact that the two religious cults agreed to share and alternatively perform religious services in only 19 churches. Even this limited retrocession took place after bitter juridical and ecclesiastical polemics. While the Cathedral in Lugoj was returned through the good will of the local Metropolitan Orthodox Nicolae Corneanu, the return of the historical Greek-Catholic Cathedral in Blaj occasioned acrimonious debates. When the local Orthodox pastor announced his conversion to Greek-Catholicism and turned the cathedral over to the Greek Catholic Church, Patriarch Teoctist vehemently denounced this "Catholic aggression", and announced his intention to break all ecumenical ties with Vatican ${ }^{11}$. This situation provoked deep frustrations for Greek-Catholic hierarcs : in September 1991, Cardinal Todea went so far as to declare that «the Uniate Church considers herself as being persecuted in Romania by other Romanians $»^{12}$. 

the inter-confessional conflict acquired a new political significance. The new ruling coalition was dominated by the National Peasant Christian Democratic Party (NPP), established in 1926 by the merge between The Peasant Party in the Old Kingdom, and the Romanian National Party in Transylvania. The NPP encompassed thus a strong Greek-Catholic component: the most illustrious interwar leader of the party and subsequently its cult figure, Iuliu Maniu, was a Greek-Catholic from Blaj. Revived after 1989, the NPP has adopted the Christian Democratic ideology, and has become, since 1992, a member in the Christian-Democratic International. Since the ruling NPP defined Christian morality as the basis of its political doctrine and opposed the legacy of secularization of social life enforced by the communist regime, the Church has been able to make important gains in consolidating her profile. Suffice it to mention that Romania became one of the few countries in Europe in which the study of religion was made compulsory in state elementary schools. The Orthodox leadership took full advantages of the new political circumstances, but it remained, however, very insecure, fearing governmental support for the rival Greek-Catholic Church. Indeed, GreekCatholics also felt encouraged in their demands for historical justice by the new political context, since one of the most representative political slogans of the new ruling coalition was the restitution of the property nationalized by the communist regime. Consequently, the Greek-Catholics intensified their propaganda, at the precise moment when the Orthodox Church became more unwilling to compromise.

The result was an aggravation of the acrimonious strife between the hierarcs of the two confessions, expressed through a veritable "war of words". It became imperative that the government intervenes to cut the Gordian knot through legislative means. The "Boila Bill", adopted by the Senate (the upper chamber of the Romanian Parliament), in June 1997, stipulated that the Orthodox Church was obligated to return churches to Greek Catholics, upon demand, in localities where there are several Orthodox churches. The bill provoked an immense public scandal, with incendiary reactions from most of the important Orthodox high hierarcs. Patriarch Teoctist portrayed the bill as «a dictate with unexpected consequences for the peace of Transylvania ${ }^{13}$; Iunian, the Bishop of Satmar, threatened that the new law could transform Transylvania « into a Belfast or a new Yugoslavia $»^{14}$, while the Association of the Orthodox Christian Students unequivocally characterized the bill as «legal support for Catholic proselytizing campaign in Transylvania $»^{15}$. Consequently, the Orthodox Church launched a virulent campaign against the new parliamentary bill : on September 18, 1997 a public of the Romanian Orthodox Archbishops from Transylvania was transmitted to all members of the Romanian Parliament, while the Orthodox Patriarch Teoctist appealed personally to Ion Diaconescu (the head of the Chamber of Deputies, the lower chamber of the Romanian Parliament), to oppose the bill. Due to this extraordinary pressure on the political power, the Chamber of Deputies ultimately rejected the bill.

The political power proved thus incapable of imposing a compromise solution. Moreover, on the political arena, the conflict provoked sharp disagreements within the ruling coalition itself, between the Democratic Party and the National Peasant Christian Democratic Party. More significantly, it provoked acute controversies within the most important party of the ruling coalition, the National Peasant Christian Democratic Party, with Orthodox and Catholic deputies opposing each other in vitriolic 
parliamentary debates. Thus, the Greek-Catholic priest Ioan Moisin, a NPP's senator, characterized the political demonstration of Orthodox priests in March 1998, as "Orthodox Phariseism", a sign of Orthodox inflexibility and stubbornness. In reaction, another NPP's senator, the Orthodox priest Ioan Roman, protested against this "irresponsible" declaration, and denounced the duplicity of the Greek-Catholic Church, which "pressured secretly" the political power for a favorable solution to their demands ${ }^{16}$.

With the failure of a mediating political solution, the relationship between the two churches reached a complete deadlock. The negotiation process - which reacquired a central role in the contention - was once again stagnating. The establishment, in February 1998, of a new central commission for dialogue, proposed by the Holy Synod of the ROC, has been unable to give the necessary boost to the negotiations. Instead, it was clear that the two churches had abandoned the dialogue and operated significant changes in their conflict strategy. While the Uniate Church tried to reach its objective by influencing public opinion and political factors, the ROC chose to mobilize her priests and believers in public manifestations. In this way, the conflict reached a new stage, that of open grass-roots level confrontation among the rank and file priests and ordinary believers. On March 13, 1998, the violent confrontation between Orthodox and Greek-Catholic believers in the Church "Schimbarea la Fata" (the Transfiguration) in Cluj, was widely reported by media, and provoked genuine emotion and consternation throughout the country. Nevertheless, in response to the Greek-Catholic occupation of the church, Orthodox priests chose to further escalate the conflict by protesting publicly during marches and processions in various ecclesiastical centers throughout the country. On March 20, 1998 Bartolomeu Anania, the Orthodox Archbishop of the Transylvanian diocese of Vad, Feleac and Cluj, led an impressive march of protest of 2500 Orthodox priests and students in Cluj. Thus, instead of being a factor of equilibrium in society, inter-confessional relationships in Romania seemed to be rapidly deteriorating, reproducing the lines of the acrimonious political conflicts.

In the face of increased pressure from the Greek-Catholic Church, the ROC has also launched a political offensive aimed at questioning the existing legally established relationship between church and state. On mid-April 1998, Orthodox Archbishop Bartolomeu Anania called for a direct interference of the Church on the political scene. In his opinion, the Church needed to become a major factor of moral orientation within political life, mainly by recommending a certain political party to the electorate. Although according to the status of the ROC, such a decision could be taken only by the Holy Synod of the ROC, it was nevertheless telling that Anania's proposal was soon backed by many Orthodox prelates. Their controversial declarations stirred fierce debates in Romanian society, first and foremost because they contradicted the Constitution of Romania. Although individual priests have the right to enroll in political parties, the Church as a public institution cannot directly participate in the political life of the country or express partisan political beliefs. The chasm between the Orthodox Church and intellectuals seemed thus to widen yet again : a communiqué of the Civic Alliance, the most influential Romanian civic organization, condemned unambiguously the intention of the Orthodox Church to morally censure the political life, highlighting its potential negative impact upon civil society in Romania. By contrast, nationalist parties were instead unanimous in supporting a direct political implication of the Church. Gheorghe Funar, the mayor of Cluj, the largest city in Transylvania, and at the time the nationalist leader of the Alliance for the Unity of 
Romania, tried to exploit politically the controversy by placing it within the context of inter-ethnic relations in Romania ${ }^{17}$. He advocated the political representation in Parliament of "the Romanian National Church", an old nationalist formula used to designate both the Orthodox and the Greek-Catholic Churches. In Funar's opinion, would only equalize the political profiles of religious cults in Romania, since, the Reformat and Roman-Catholic Churches "have been making politics all the time", through the political representation of the Hungarian Democratic Union in Romania ${ }^{18}$. The most vigorous reaction belonged to the ultra-nationalist Greater Romania Party, which has had close political ties with prominent neo-communist, nationalist Orthodox hierarcs ${ }^{19}$. Thus, Corneliu Vadim Tudor, the contested leader of the party, claimed it of a national urgency for the Church to enter the political battle, "so as to assure the victory of the national cause $»^{20}$.

In this way, while politicians, journalists, political analysts and high prelates were reacting to Anania's statement, it became more and more evident that the proposal was in fact the tip of the iceberg: we were actually facing a veritable political offensive of the ROC, aimed at questioning the existing legally established relationship between church and state. This state-church crisis was also a serious warning for a potential alliance between nationalist parties and a frustrated ecclesiastical leadership. It is however worth noting that most nationalist parties, while investing religious faith with an important role in defining Romanian national identity, do not openly differentiate between Orthodox and Greek-Catholics, but refer rather ambiguously to a Romanian National Church of an authochtonus tradition, composed of both "sister-churches". This attitude of nationalist parties is triggered by political interests : since one of their main electoral bases is in Transylvania, and is composed of a mixture of Orthodox and Greek-Catholic believers, they hardly can afford to neglect the interests of the local Greek-Catholic Church ${ }^{21}$. But it also expresses the dilemma of nationalist parties in taking sides, since Orthodoxy and Greek-Catholicism have been both important components of Romanian nationalism.

The religious strife had a great impact on Romanian foreign policy, as well. Beginning in 1994, Romania intensified its campaign for integration into NATO. Trying to secure valuable diplomatic support from the Vatican State, the Romanian government reestablished its diplomatic representation in Vatican, while the former Romanian president Ion Iliescu extended in a short period of time three consecutive official invitations to Pope John Paul II to visit Romania. The inter-confessional conflict hindered many of these efforts. In several occasions, the Pope specifically addressed the issue of Greek-Catholic patrimony retrocession, appealing to the Romanian government for a favorable resolution to the matter. In reaction, the dominant Romanian Orthodox Church has constantly refused to endorse a visit of the Pope in Romania, conditioning it by a preliminary reconciliation of the Orthodox and GreekCatholic Churches. Finally, in November 1997, in the midst of an intense campaign for NATO integration, the Romanian Prime-Minister Victor Ciorbea had to report that a renewed invitation for Pope's visit in Romania failed because of ROC's opposition. This gesture aimed at shaping Romania's foreign policy was by no means singular. If the Catholic Church leadership campaigned for a more determined Western orientation of Romania's policy, the Orthodox leadership has regularly taken conservative stances in major social-political issues, a fact which led some analysts to go so far as to appreciate that the Orthodox Church " has launched a battle against the West ${ }^{22}$. For instance, the Orthodox Church vigorously opposed the legalization of homosexuality in Romania - in 
spite of the fact that any delay in the harmonization of Romanian legislation with the European standard would unavoidable hinder Romania's potential integration into the European Union. Later, the ROC strongly opposed any collaboration between Romania and NATO in implementing a military solution in the Kosovo crisis against Yugoslavia. Far from being a simple demonstration of Orthodox solidarity, the gesture was suspect of expressing also a political option of the ROC. In this way, in their conflict, Orthodox and Greek Catholic theologians took sides in the continuous ideological debate between Westernizers, Indigens and pro-Orientals, an issue which has monopolized the Romanian socio-political and cultural disputes in the modern period ${ }^{23}$.

\section{The Relationship between Religion and National Identity : A Recurrent Dilemma}

In evaluating this inter-confessional debate, it is important to note that the theological aspects of the Orthodox-Catholic rivalry proved marginal. Instead, legal arguments prevailed: the RGCC representatives denounced the abusive confiscation of their property by the communist regime and appealed for legal and historical justice. They argued that the reunification synod, held in October 1948 in Bucharest was noncanonical, since it was not initiated by Greek-Catholic clerics and believers, but was instigated by an aggressive Orthodox leadership, and inspired by a visit in Bucharest of the Patriarch of the Russian Orthodox Church in early 1948. At the synod a mere 430 Uniate priests participated, out of a total of 1800 ; significantly, none of the Uniate bishops either participated or endorsed the unification act. The ultimate responsibility for disbanding the Greek-Catholic Church belongs thus to the Romanian state, which, in the Decree $n^{\circ} 358$ in 1948, forbade the Greek-Catholic Church and handed over her properties to the Orthodox Church. This argument formed the backbone of the GreekCatholic thesis : if the Romanian state confiscated abusively their church's property, it would consequently result that it is the legal duty of the state to return it, in integrum, to the former owner.

By contrast, Orthodox representatives pictured the 1948 ecclesiastical synod as «the saint act of reunification of the Mother-Church, at the initiative of the Greek-Orthodox clerics and believers ${ }^{24}$. They point to the abrogation of the Concordat between Romania and the Vatican state by the communist government in early 1948, arguing that, as a consequence of it, Greek-Catholic property became subject to the Romanian legislation, which asserted that the property of parishes belongs to the members of the local congregation. Consequently, in 1948, the Greek-Catholic believers "returned to the Orthodox Church together with their churches, parochial houses and their entire religious patrimonies $\aleph^{25}$. This demonstration was meant to reverse the thesis put forward by the Uniate Church, by arguing that the Greek-Catholic patrimoine was not confiscated by the state, but transferred to the Orthodox Church through the consensual conversion of the believers, a situation that was merely consecrated by the government through a later decree. Consequently, a retrocession of Greek-Catholic property can be made only through amiable inegotiations between the two churches, and only according to the numerical proportion of Greek-Catholic believers at the local level. Since the Uniate Church has shrunk to 228000 members, it would result that Greek-Catholics are entitled to only a limited share of their former property. 

Greek-Catholic elites chose to lobby the political power for a juridical solution to their retrocession demands ; by contrast, deprived of its previous political ties, the Orthodox leadership rejected any state mediation in the conflict. The violent March 1998 incident in Cluj was eloquent in this respect: following a favorable decision of the Supreme Court of Justice, Greek-Catholics believers occupied the Church "Schimbarea la fata" against firm Orthodox resistance. On the Orthodox side, the juridical decision was considered illegitimate. As the local Orthodox priest of the Church "Schimbarea la fata" declared : «We will not obey the law, since the Romanian system of justice itself does not obey the lay, in a situation in which tens of thousand believers are thrown out of a religious edifice simply because the Court took into account only the right to property $»^{26}$. As we can see, faced with an intense Greek-Catholic retrocession campaign, Orthodox hierarcs expressed fears of a conspiracy between the political power and the Catholic Church against Orthodox interests : an official communiqué by the Orthodox Archbishopry of Vad, Feleac and Cluj, portrayed the violent incident in Cluj as a «Greek-Catholic aggression, prepared, consumed and finalized under the protection and with the complicity of the Cluj Police, manipulated by the militant Greek-Catholic prefect of the Cluj county, Alexandru Farcas, the brother-in-law of the Senator Matei Boila $»^{27}$. This argument was in fact a recurrent theme in Orthodox propaganda, being directly linked to an alleged Catholic proselytizing campaign directed towards Orthodox believers. The Greek-Catholic retrocession campaign was thus portrayed as meant to offer "a legal basis for Catholic proselytizing among Orthodox believers, since its real aim is not to obtain religious edifices, but to convert to Catholicism the Orthodox believers who traditionally go to those churches $»^{28}$.

Significantly, the content of the recent inter-confessional debate exhibits striking similarities with the arguments advanced by theologians in the interwar period. In 1928, a Parliamentary Bill regarding the Legal Status of Religious Cults - meant to prepare the ratification of the 1927 Concordat between Romania and the Vatican triggered vehement Greek-Catholic protests. The Uniate Church was protesting the stipulation that in the situation of a conversion en masse of the believers of a local parish the property would automatically be transferred to that church whose members were in majority ${ }^{29}$. This principle was contrary to the Catholic law that asserted that the property of a Catholic parish was the prerogative of the bishop. In opposing the Bill, Greek Catholic clerics organized massive protests in several Transylvanian cities during which there were numerous violent clashes with the police. The debate was later transferred to the benches of the Senate, where the Greek Catholic and Orthodox leaderships engaged in heated polemical speeches ${ }^{30}$. Finally, the controversial article was omitted from the Law of the Cults adopted in 1928. The following year (1929), the ratification of the 1927 Concordat between Romania and the Vatican was bitterly criticized by an insecure Orthodox leadership, which claimed that it conferred a privileged position to the Catholic Church in Romania. According to the Concordat, Catholic institutions, such as orphanages, schools and hospitals, were freed from governmental control, and this giving rise to the Orthodox fear that the Catholic Church was "a state within the state". As a result, Orthodox hierarcs pursued a virulent press campaign against the Concordat, especially through Patriarch Miron Cristea and Transylvanian Metropolitan Nicolae Balan ${ }^{31}$. As a result, the intense theological debates exceeded purely ecclesiastical arguments. In their attempts to defend their interests, theologians assumed an active role in the debates concerning Romanian national 
identity ("specificul national") and the path of development. They attempted thus to develop a symbolic-ideological control over the nation, by defining the Orthodox church as the national spiritual leader, the main repository of Romanian traditional values. The most representative phenomenon of this trend was the birth of Orthodoxism, a school of ideas centered on the magazine Gandirea [the Thought], which transformed Orthodoxy into an ism, an ideology. The salient characteristic of Orthodoxism was the reevaluation of the relationship between religion and nationality in Romanian national ideology, in the form of religious nationalism. The interwar journalist, university professor and Orthodoxist philosopher Nae Ionescu created the most authoritative syntagm of integral nationalism in interwar Romania : "we are Orthodox because we are Romanians, and we are Romanians because we are Orthodox $\|^{32}$. Ionescu's formula united in a penetrating synthesis two of the fundamental elements of Romanian national ideology : the peasant as a repository of ethnic purity and traditional national values, and the Orthodox religion as a fundamental characteristic of Romanian spirituality. Furthermore, Ionescu's definition of Romanian identity operated a syncretism between Orthodoxy and nationality, which, given the pluri-confessionalism of the Romanians, symbolically excluded a significant part of them from the national community.

The way in which many legal, political and ideological arguments of this traditional debates recur under contemporary circumstances is very striking. An "official" contemporary historian of the Orthodox Church in Romania, Mircea Pacurariu, considered that, as a result of the 1927 Concordat, the Romanian Orthodox Church was placed « in a state of inferiority and humiliation in comparison to the Roman-Catholic and other cults in Romania $»^{33}$. The reasons invoked by Pacurariu highlighted specifically the competition for resources among the religious cults in Romania. He accused that « the number of counselors and Catholic priests employed by the state [was] greatly superior to the Orthodox one (...) with substantially better salaries than the clerics of the Romanian Orthodox Church $»^{34}$. From the same perspective, Patriarch Teoctist argued in 1997 that « the Greek-Catholic Church lives today in the nostalgia of the period 1929-1948, when the Concordat between Romania and the Vatican assured her a privileged status, breaking thus the Constitution, the Law Regarding the Status of Religious Cults, and the equality between religious cults $»^{35}$.

Furthermore, although the post-1989 confessional conflict took place in the secular realm and was part of the more general problem of post-Communist property retrocession, it is very telling that - similarly to the interwar period - Orthodox and Greek-Catholic theologians went beyond legal or ecclesiastical polemics, composing instead competing discourses on Romanian national identity. Its first public statement from January 8, 1990, the Uniate Church conceived Greek-Catholicism as an essential component of the national identity of the Romanians : « the Romanian Uniate Church is (...) the institution of Latinity of the Romanian people $»^{36}$. It also portrayed the GreekCatholic Church as a link between Romania and the Western world: «the Romanian Uniate Church is a religious, but also a national institution. Because it is Catholic, it loves its people first of all, but addresses it, through its Catholicity, in a European and universalistic spirit $\aleph^{37}$. By contrast, Orthodox theologians portrayed the establishment of the Greek-Catholic Church as a departure from the Romanian national tradition, which divided Romanians into different confessions, and opened the Pandora box of inter-confessional disarray and competition. Instead, they underlined the central role played by the Orthodox faith in the formation of the Romanian people, the only one in 
East Central Europe to be Christian "from its very genesis"; they also stressed the unique combination of Latin blood and Orthodox spirituality which assured the specificity of the Romanian identity and prevented the denationalization of Romanians. The identification of the Romanian Orthodox Church with the Romanian people, of Greek-Catholics with "foreigners", and respectively, of the post-1989 confessional discord with the 1692-1700 events - were constant elements of Orthodox propaganda. Thus, Antonie, the Metropolitan of Transylvania, portrayed the Greek-Catholic retrocession campaign as "an attack against the Romanian Orthodox Church and against our people ", and he warned politicians «not to repeat the events from 1700, when foreigners caused wounds and sufferings $»^{38}$. In the same vein, a letter by the Holy Synod of the ROC appreciated that a solution to the litigation concerning the Greek-Catholic property «can be reached only by taking into account the integral aspect of the problem, from 1700 to present", since "the split of the Orthodox Romanians from Transylvania " was achieved by the Roman Catholic Church and Habsburg authorities by "using false documents, unfulfilled promises and deceiving $»^{39}$. Consequently, the 1700 religions union which established the rival GreekCatholic Church was an illegitimate religious act, performed not by conviction «but because of social, political or economical reasons $»^{40}$. In contrast, Orthodox representatives suggested a symbolic identification between Orthodoxy and the Romanian people, which often took anti-democratic, nationalist overtones : in a speech during the Orthodox procession in Cluj on March 20, 1998 Orthodox Archbishop Anania warned that, similar to 1700 , "waves of enemies rise again against the Romanian Orthodox Church, and through her, against the Romanian nation ${ }^{41}$. Rejecting any political intrusion in the life of the Church, Anania cautioned that today although « we do not have war between us yet, we have disarray " and that " our Cross will be firm »" Finally, the official Orthodox celebration of the $50^{\text {th }}$ anniversary of the 1948 synod, on October 21, 1998, reiterated this position. The 1948 religious "reunification" was again placed against the original schism of Greek-Catholics from the Orthodox Church in 1700 , and charged with powerful nationalistic overtones: the commemoration took place at "the Cathedral of National Reunification" in Alba Iulia, and was linked with the celebration of the Orthodox saints who revived Orthodoxy in Transylvania in the $18^{\text {th }}$ century, by opposing the offensive of the Greek-Catholic Church ${ }^{43}$. In this way, instead of giving pre-eminence to their "Romanianness" as the strongest bound in their relationship, the Orthodox and Greek-Catholic leaderships chose to monopolize the definition of a "real Romanian". This strategy served at symbolically excluding the rival confession from the national community, and of curbing thus the competition for material resources and spiritual domination.

\section{Conclusions}

Following the violent incident in Cluj, the conflict between the two churches seemed to gradually de-tension. In October 1998 was initiated the first genuine post-1989 negotiation process between the two churches, at the initiative of the Orthodox Church and with mediation of an observer from Vatican. A meeting between a delegation of the ROC led by Daniel, the Metropolitan of Moldova and Bucovina, and a delegation of the Uniate Church led by Metropolitan Lucian Muresan, was reported as a breakthrough in the dispute ${ }^{44}$. 
The process of reconciliation proved to be slow and strenuous, since, after years of open confrontations, antagonistic reflexes are still persisting. Thus, parallel to the initiation of a new negotiation process, the Romanian Orthodox Church chose to celebrate in October 1998 and for the first time in her history, the $50^{\text {th }}$ anniversary the 1948 "reunification" synod. Nevertheless, the October bilateral meeting seemed to mark the beginning of a period of improved inter-confessional tolerance in Romania. In January 1999, fifteen high hierarcs of the Greek-Catholic and Orthodox Churches signed an agreement intended to put an end to a period of nine years of acute polemics and violent confrontations. Without solving all the contentious problems, the document, celebrated by Romanian media as "the Peace from Blaj", reinstated the dialogue as the only mean of solving inter-confessional disputes ${ }^{45}$. Following the request of the Orthodox Church, the Greek-Catholic Church has committed herself to withdrawing all the current juridical and legislative actions addressing the issue of patrimony retrocession, and to renounce any attempt of forceful occupation of religious edifices, or to encourage proselytizing actions. In exchange, the Orthodox Church has recognized the Greek-Catholic de facto possession over approximately 100 religious edifices acquired after 1989, regardless the manner they were obtained; and expressed its willingness to establish mixed local commissions for negotiating further retrocession in rural localities where there are several Orthodox churches, but only upon demand and providing that there is a consensual agreement of the local Orthodox priest and believers. The two parts still disagreed on church retrocession in urban localities, and sought for solutions in localities in which there exists only one religious edifice for both communities.

This confessional reconciliation has removed thus the major domestic stumbling block against the visit of Pope John Paul II's in Romania. However, the itinerary and the specific content of his visit occasioned yet another competition for symbolic capital between the two churches. Greek-Catholics exercised a strong lobby for the Pope's visit to their ecclesiastical center in Blaj ; in March 1999, a manifest signed by 50 leading Romanian politicians supported their intention. By contrast, radical Orthodox factions expressed concerns that the visit of the Pope is an integral part of a concerted Catholic proselytizing campaign for regaining to Greek-Catholicism millions of Romanians and Ukrainians. Their opposition was strengthened by the intransigent attitude of the Russian Orthodox Patriarch Alexei, who, in exchange for a refusal of the Romanian Orthodox Church to endorse the Pope's visit, expressed his readiness to negotiate an extension of the jurisdiction of the ROC in Bessarabia ${ }^{46}$. Ultimately, the visit of the Pope John Paul II in Romania, which occurred in May 7-9, 1999, was a major political success for the Orthodox Church, being appreciated by the Romanian Foreign-Minister, Andrei Plesu, as «a decoration on the Patriarch's robe $»^{47}$. Through strained negotiation, the Romanian Orthodox leadership prevented a visit of the Pope in Transylvania. In this way, while reducing the religious significance of the Pope's visit for the rival GreekCatholic Church, the Romanian Orthodox Church could exploit fully the political benefits of the event. The visit of the Pope consecrated the reconciliation between the Greek-Catholic and the Orthodox Churches : in a third bilateral meeting at Rimet, in June 14, 1999, the Greek-Catholic Church has abandoned the principle of restituio in integrum of her former property, limiting her request to 160 churches and 70 religious edifices $^{48}$. It also suggested a decisive emancipation of the Romanian Orthodox Church from the political influence of Moscow, increasing thus its domestic and international prestige. On a more general level, the first visit of a Pope in a preponderant Orthodox 
country was meant to signal an epoch of renewed confessional dialogue between Orthodoxy and Catholicism ${ }^{49}$. In the midst of the Kosovo crisis, the Pope and the Patriarch appealed for an end to the war and the implementation of a diplomatic solution to the conflict.

In conclusion, the resurrection of the Greek-Catholic Church in post-1989 Romania was partially successful. Following the 1989 political change, the Greek-Catholic Church was in a political offensive, favored by its ties to the Vatican and by Romania's efforts at building a democratic society and at gaining access to European institutions. The newly revived church enjoyed thus the sympathy of numerous politicians, intellectuals and emerging civil associations. By contrast, after the collapse of the communist regime the Orthodox Church was quasi-isolated and had to face an increased pressure for internal reforms : numerous intellectuals expressed concerns that the tradition of the Orthodox Church in supporting authoritarian political regimes and its conservatism could hinder the development of civil society and Romania's aspiration for Western integration. In this context, the inter-confessional conflict over patrimony retrocession had a great impact on shaping the post 1989 trajectory of the two churches : lacking a strong mass basis, the Greek-Catholic elites chose to use political and juridical means for attaining their objectives; by contrast, an isolated Orthodox leadership opted for a populist Orthodoxism, with powerful nationalist overtones. However, Greek-Catholics were soon trapped in their strategy of elitist political lobby: the ruling National Peasant Christian Democratic Party proved unable to foster a Christian-Democratic movement, similar to the kind of social activism that characterizes Western Christian Democracy. Instead, the party was torn by the competing interests of its Orthodox and GreekCatholic factions ; ultimately, failing to reach its maximal objectives, the main Greek Catholic interest group, centered around the Greek-Catholic priest Matei Boila, defected the NPP and formed the Christian-Democratic Alliance. The end of the conflict found thus the Romanian Orthodox Church engaged in a genuine political offensive. Nevertheless, on the long run, the strategy of connecting the religious conflict to the sharp debates over national ideology in Romania proved to be a winning card for the ecclesiastical leadership : consequence of the conflict, the symbolic capital of the two churches has paradoxically increased. In May 1999, invoking their contribution to achieving the much-desired religious reconciliation, Romanian President Emil Constantinescu decorated the leaders of the Romanian Orthodox and Greek-Catholic Churches, namely the Orthodox Patriarch Teoctist and the Greek-Catholic Cardinal Alexandru Todea, in a gesture meant to symbolize a restored collaboration between the Church and the political power in Romania.

\section{NOTES}

1. Weber (Max), Basic Concepts in Sociology, New York: The Citadel Press, 1963, pp. 122-123. See also Economy and Society. An Outline of Interpretive Sociology, Berkeley: California Press, 1978, Vol. II, chapter XV « Political and Hierocratic Domination ». 
2. For the most authoritative study of the debates over Romanian national identity, see Verdery (Katherine), National Ideology Under Socialism. Identity and Cultural Politics in Ceausescu's Romania, Berkeley : University of California Press, 1991.

3. The Byzantine legacy in the domain of church-state relationship is usually described pejoratively as caesaropapism, a concept which asserts that, in opposition to the West, where the Catholic Church was independent from the political power, in Byzantium the emperor exercised a strong political control over the church.

4. Following strong international pressure from the European Congress in Berlin (1878), Article 7 of the 1866 Romanian Constitution was ultimately revised in 1879 , to read that « in Romania, the difference of religious belief and confession can prevent neither the accession to civil and political rights, nor the exercise of these rights». The procedure of naturalization of nonChristians remained however very slow and restrictive, being granted only individually by a vote of the Parliament.

5. Banac (Ivo), « Political Change and National Diversity » Daedalus, September 1994.

6. See Prundus (Silvestru), Plaianu (Clemente), Catolicism si ortodoxie romaneasca. Scurt istoric al Bisericii Romane Unite (Catholicism and Romanian Orthodoxy. A Short History of the Romanina Uniate Church), Cluj-Napoca : Viata Crestina, 1994 ; and Marcu (Vasile), Drama Bisericii Romane Unite cu Roma (greco-catolica). Documente si marturii (The Drama of the Romanian Greek-Catholic Church United with Rome. Documents and Testimonies), Bucharest : Crater, 1997.

7. See Article 29, "The Liberty of the Consciousness ", The Constitution of Romania, November 21, 1991.

8. For a virulent criticism of an alleged concerted post-1989 neo-protestant proselytizing campaign in Romania, see Daniel (the Metropolitan of Moldova and Bucovina), «Democratie si Prozelitism » (Democracy and Proselytizing), Candela, April 1997.

9. See editorials by Cornel Nistorescu in the daily newspaper Evenimentul Zilei [the Event of the Day], such as «Diavolul si bunul Dumnezeu» (the Devil and the Mighty God), 27/06/97; «Securistii si Biserica " (The Securitatea's Officers and the Church), 08/07/97.

10. For an attempt to analyze these historiographic stereotypes, see Petrescu (Dragos), « Despre vocatia democratica a tarilor "ortodoxe" " (About the Democratic Vocation of the "Orthodox" Countries), Sfera Politicii, (69), June 1999.

11. See Ionescu (Dan), "The Orthodox-Uniate Conflict», Report on Eastern Europe, 2 (31), 02/08/91.

12. «Cardinalul Dr. Alexandru Todea in vizita arhiereasca la Cluj » (Cardinal Alexandru Todea in Visit to Cluj), Viata Crestina [Christian Life], 2 (18), September 1993, p. 3.

13. Quoted in Evenimentul Zilei, 10/06/97, p. 4.

14. Ibid.

15. Ibid.

16. See Evenimentul Zilei, 22/03/98, p. 4.

17. Currently, Gheorghe Funar is the Secretary General of the ultra-nationalist Greater Romania Party, led by Corneliu Vadim Tudor.

18. Quoted in Evenimentul Zilei, 16/04/98, p. 4.

19. Nestor, the Metropolitan of Transylvania, and Antonie, the Metropolitan of Oltenia, were reported to have close political links with GPR. See Chachir (Dan), « Doi mitropoliti se inchina unui aventurier» (Two Metropolitans make allegiance to an adventurer), Cronica Ortodoxa [The Orthodox Chronicle], Vol. II, Bucharest : Timpul, 1997, pp. 145-146.

20. Quoted in Evenimentul Zilei, 10/06/97, p. 4.

21. This is mostly true for the Party of Romanian National Unity (PRNU), whose electoral base is almost exclusively in Transylvania, and whose main political message is built around the nationalistic theme of an alleged Hungarian security threat to Romania. As for the Greater Romania Party (GRP), his political ties and xenophobic message favors greatly the Romanian 
Orthodox Church. Nevertheless, the recent merge between a scission from the PRNU, called "the Alliance for the Unity of Romania" and led by Gheorghe Funar and GRP in November 1998 brings interesting new elements to this equation.

22. See Mugiu-Pippidi (Alina), «Identity Crisis », Transition, 2 (7), 05/04/96.

23. Terms coined by Verdery (Katherine), op.cit., p. 47. For the Romanian debates on dependency and modernisation see Jowitt (K.), Social Change in Romania 1860-1940: A Debate on Development in a European Nation, Berkeley : University of California, 1978.

24. See "the Letter $n^{\circ} 6974$ addressed by Patriarch Teoctist to the head of the Romanian Chamber of Deputies, Ion Diaconescu », 18/11/97.

25. "The Letter of the Holy Synod of the ROC Addressed to the Chamber of Deputies, Concerning the Retrocession of Some Religious Edifices to the Romanian Catholic Church United with Rome (Greek-Catholic) initiated by the Senator Matei Boila », 11/12/97, p. 3.

26. Quoted in "Biserica "Schimbarea la Fata" le ramine greco-catolicilor" (The Church "Transfiguration" remains Greek-Catholic), Evenimentul Zilei, 22/02/98, p.16.

27. "O pata rusinoasa in istoria constiintei românesti » (A Shameful Trauma in the History of the Romanian conscience) [Official Communiqué of the Orthodox Archbishopry of Vad, Feleac and Cluj], Evenimentul Zilei, 15/03/98, p. 16.

28. Statement by Daniel, the Metropolitan of Moldavia and Bucovina, Evenimentul Zilei, 10/06/98, p. 4.

29. Niessen (James), «The Greek-Catholic Church and the Romanian Nation in Transylvania », in Niessen (James), ed., Religious Compromise, Political Salvation. The Greek Catholic Church and Nationbuilding in Eastern Europe, Pittsburgh : University of Pittsburgh [The Carl Beck Papers in Russian and East European Studies, (1003)], 1994, p. 58.

For a brief overview of the polemics, ibid.

30. See speeches by Greek-Catholic bishop Iuliu Hossu, Orthodox Patriarch Miron Cristea and Nicolae Balan, Orthodox Metropolitan of Transylvania, in Biserica noastra si cultele minoritare. Marea discutie parlamentara in jurul Legii cultelor (Our Church and the Minority Cults. The Great Parliamentary Debate around the Law concerning the status of religious Cults), Bucharest, 1928.

31. See his brochure Biserica neamului si drepturile ei (The Church of the Nation and its Rights), Bucharest, 1927.

32. Ionescu (Nae), Roza Vînturilor (Compass card), Bucharest, 1937, p. 201.

33. Mircea Pacurariu is an Orthodox priest and professor of theology in Sibiu, Transylvania. Recently, his book (Pacurariu(Mircea), The History of the Romanian Orthodox Church (Bucharest, 1981), in three volumes), was reedited by the Biblical Institute for Christian Mission of the Romanian Orthodox Church, at the recommendation of Romanian Patriarch Teoctist. See Vol. III, p. 420.

34. Ibid., pp. 420, 423.

35. "The Letter of the Holy Synod of the ROC to the Chamber of Deputies ", 11/12/97, p. 7.

36. See Kirche und Glaube in Rumänien, Munich, 1990, pp. 123-266 ; and Nierssen (James), art.cit., p. 61.

37. Ibid.

38. Quoted in Evenimentul Zilei, 10/06/97, p. 4.

39. "The Letter of the Holy Synod of the ROC to the Chamber of Deputies ", 11/12/97, p. 5.

40. Ibid., p. 6

41. Ibid., p. 4.

42. Ibid.

43. "The Cathedral of National Reunification" from Alba Iulia is regarded as a symbol of Romanian national unity. There was proclaimed, at December 1, 1918, the union of Transylvania with Romania.Reported in «Biserica Orthodoxa Romana comemoreaza Sfintii Ardeleni » (The Romanian Orthodox Church Commemorates Transylvanian Saints), Evenimentul Zilei, 21/10/98. 
On the Orthodox reaction against the Union, which culminated in the 1744 uprising led by the Serbian monk Visarion, see Hitchins (Keith), « Religion and Romanian National Consciousness in Eighteenth-Century Transylvania », Slavonic and East European Review, 57 (2), 1979.

44. «Dupa un razboi de cincizeci de ani » (After a Fifty Years War), Evenimentul Zilei, 28/10/98.

45. See « The Peace from Blaj ", in Ziua [The Day], 29/01/99, p. 4.

46. Reported in Evenimentul Zilei, 22/02/99, p. 3.

47. Zubascu (Ion), « Interview with Andrei Plesu », Romania Libera, 22/04/99, p. 2.

48. Evenimentul Zilei, 14/06/99, p. 4.

49. In mid-May 1999, the Pope described his Visit in Romania as historical, and stated that Romanian Orthodox and Greek-Catholics believers are now « genuinely more united in their faith and love toward each-other ». See Evenimentul Zilei, 14/05/99.

\section{ABSTRACTS}

Romanian national ideology encompass a religious dimension with two main components : orthodox christianity and Greek catholicism (in Transylvania). The author examines how these two churches have used the symbolic bond between religion and national identity to legitimize their competing interests and the impact of this religious conflict on Romanian domestic and foreign policy.

\section{AUTHOR}

\section{CONSTANTIN IORDACHI}

University of Budapest. 